\title{
PENGARUH SUPLEMENTASI STARBIO DALAM PAKAN DENGAN 40\% DEDAK PADI TERHADAP PENAMPILAN BABI LANDRACE
}

\author{
SUMADI I.K., GEDE WIJAYA I. M., DAN PUGER A.W. \\ Fakultas Peternakan, Universitas Udayana \\ Jl.PB Sudirman, Denpasar - Bali \\ e-mail: i.k.sumadi@gmail.com
}

\begin{abstract}
ABSTRAK
Penelitian bertujuan untuk mengetahui penampilan babi landrace yang diberi pakan mengandung 40\% dedak padi dengan suplementasi Starbio. Penelitian ini menggunakan babi landrace sebanyak 12 ekor dengan berat badan antara 20-30 kg. Pakan terdiri dari konsentrat Guyofeed, dedak padi dan jagung kuning. Rancangan penelitian yang digunakan adalah rancangan acak kelompok (RAK); 4 kelompok berat badan yang diberi 3 macam pakan perlakuan. Pakan yang diberi dengan 40\% dedak padi tanpa suplementasi Starbio sebagai kontrol (perlakuan A); pakan dengan 40\% dedak padi dan disuplementasi o,2\% Starbio (perlakuan B); dan pakan dengan 40\% dedak padi dan disuplementasi 0,4\% Starbio (perlakuan C) selama 6 minggu. Data yang diperoleh dianalisis dengan analisis sidik ragam dan bila terdapat perbedaan yang nyata diantara perlakuan $(\mathrm{P}<0,05)$ dilanjutkan dengan uji jarak berganda Duncan (Steel dan Torrie, 1989). Dari hasil penelitian dapat disimpulkan bahwa suplementasi Starbio dalam pakan dengan 40\% dedak padi mampu memperbaiki penampilan (konsumsi pakan, pertambahan berat badan, energi tercerna, dan profil kotoran) babi landrace.
\end{abstract}

Kata kunci: babi landrace suplementasi, starbio, penampilan, profil kotoran

\section{THE EFFECT OF STARBIO SUPPLEMENT ON DIET WITH 40\% OF RICE BRAN TO THE PERFORMANCE OF LANDRACE PIGS}

\begin{abstract}
The aims of the research are to know the performance of landrace pigs which is given the ration that use $40 \%$ of rice bran with Strabio suplement. This experiment used twelve landrace pigs with live weight of 20-35 kg. The ration concists of Guyofeed concentrate, rice bran, and yellow corn. Randomized completely block design with three treatmens while each treatment concists of four blocks were used in this study. The three given treatments were the ration with $40 \%$ rice bran without Starbio supplement as a control (treatment A); the ration with $40 \%$ rice bran and 0,2\% Starbio supplement (treatment B); the ration with 40\% rice bran and 0,4\% Starbio supplement (treatment C) for 6 weeks. The obtained data were analyzed by the analysis of variance and followed by Duncan's multiple range test method (Steel and Torrie, 1989) when the significant differences among the treatments $(\mathrm{P}<0,05)$ were observed. The result of this study shows that Starbio supplement on $40 \%$ rice bran diet can improve the performance (feed consumption, live weight gain, DE, FCR and feces profile) of landrace pigs.
\end{abstract}

Key words: landrace pigs, supplement, starbio, performance, feces profile

\section{PENDAHULUAN}

Perkembangan peternakan babi sangat pesat di Bali, sehingga penyediaan bahan-bahan pakan juga harus memadai. Pemanfaatan limbah pertanian dan limbah hasil pertanian sebagai bahan pakan babi merupakan hal yang sangat lazim, sebab babi dengan mudah dapat memanfaatkan bahan-bahan dari limbah tersebut sebagai makanannya. Selain itu, bahan-bahan pakan dari limbah harganya relatif lebih murah, namun perlu diingat bahwa ternak babi merupakan ternak monogastrik, sehingga kemampuan mencerna bahanbahan pakan berserat sangat terbatas. Salah satu limbah hasil pertanian adalah dedak padi. Kualitas dedak padi di Indonesia tidak sama, karena proses penggilingan gabah menjadi beras menggunakan mesin yang berbeda-beda.

Secara umum kualitas dedak padi sebagai salah satu bahan penyusun pakan babi cukup memadai, meunurut Scott et al. (1982) dedak padi mengandung 
1630 kkal ME; 12\% CP; $13 \%$ lemak; dan 13\% serat kasar. Tingginya kandungan serat kasar pada dedak padi menyebabkan penggunaan dedak padi dalam pakan menjadi terbatas, karena ternak babi sebagai ternak monogastrik mempunyai keterbatasan dalam mencerna serat kasar (Rasyaf, 1990). Kadar serat kasar yang tinggi di dalam pakan babi akan menurunkan nilai TDN pakan sehingga dapat menurunkan pertambahan berat dan menurunkan efisiensi penggunaan pakan (Parakkasi, 1990).

Rendahnya TDN mengakibatkan kotoran babi masih banyak mengandung zat-zat makanan yang belum dicerna oleh babi. Zat makanan yang berupa protein dan zat bukan protein yang mengandung $\mathrm{N}$ akan dipecah atau diurai oleh mikroba dan hasil dari pemecahan tersebut menjadi amonia. Verstegen et al. (1999) menjelaskan bahwa gas amonia akan menimbulkan masalah seperti bau dan pencemaran udara, dan pada konsentrasi tinggi dapat menimbulkan pencemaran lingkungan dan gangguan keesehatan. Feses yang banyak mengandung air dapat meningkatkan jumlah mikroorganisme terutama E. coli, Coliform dan total mikroba.

Salah satu cara yang dapat dilakukan untuk dapat memanfaatkan dedak padi secara maksimal adalah dengan memenfaatkan starbio. Starbio merupakan antibiotika dalam media dari bubuk jerami dengan komponen bakteri yang berasal dari kayu, akar rumput, kedelai dan isi lambung sapi (Zainudin et al., 1995). Menurut Sartika et al. (1994) starbio merupakan salah satu probiotik yang dapat meningkatkan produktivitas ternak. Dijelaskan juga, starbio terdiri atas multimikroorganisme yang menghasilkan enzim yang mampu memecah lignin (lignolitik), selulosa (selulolitik), lignoselulosa (lignoselulolitik), protein (proteolitik) dan lemak (lipolitik). Starbio dalam ransum dapat meningkatkan nilai cerna ransum sehingga zat nutrisi seperti protein, lemak dan karbohidrat lebih sedikit terbuang melalui feses. Meningkatnya nilai cerna ransum akan memberikan pengaruh positif terhadap penampilan ternak. Berkurangnya zat-zat nutrisi yang terbuang melalui feses dapat diharapkan kadar amonia yang dihasilkan kotoran babi juga juga akan berkurang.

\section{MATERI DAN METODE PENELITIAN}

\section{Tempat dan Lama Penelitiann}

Penelitian dilaksanakan di Jl. Taman Wedasari No. 9, Dusun Batuparas, Desa Padangsambian Kaja, Kecamatan Denpasar Barat, Kota Denpasar. Lama penelitian enam minggu berlangsung dari tanggal 27 November 2005 sampai 08 Januari 2006. Analisis proksimat ransum, sisa ransum dan feses dilaksanakan di Lab. Nutrisi Ternak, Fakultas Peternakan Universitas Udayana, Jl. PB Sudirman, Sanglah, Denpasar.

\section{Ternak}

Babi yang digunakan dalam penelitian ini adalah babi keturunan babi landrace sebanyak 12 ekor. Berat badan awal babi-babi tersebut berkisar 20-35 kg. Babi-babi tersebut diperoleh dari peternak di Desa Padangsambian Kaja, Denpasar.

\section{Kandang dan Perlengkapan}

Kandang yang digunakan adalah kandang individual sebanyak 12 petak kandang. Tiap kandang berukuran panjang $3 \mathrm{~m}$, lebar $1,5 \mathrm{~m}$ dan tinggi $0,8 \mathrm{~m}$. Bangunan kandang dibuat dari kayu beratap asbes. Setiap petak kandang individu dilengkapi dengan tempat pakan dan tempat air minum.

\section{Pakan dan Air Minum}

Pakan yang digunakan dalam penelitian ini adalah pakan campuran antara konsentrat komersial merk Guyofeed, jagung kuning, dedak padi dan starbio. Kandungan nutrisi konsentrat Guyofeed terdiri atas: $37 \%$ protein, $4 \%$ lemak, $8 \%$ serat kasar, $18 \%$ abu, $6 \% \mathrm{Ca}$ dn $3,1 \%$ P. Semua pakan yang dipakai dalam penelitian ini berbentuk tepung (mash). Air minum yang diberikan kepada babi berasal dari air sumur setempat. Pakan dan air minum diberi secara ad libitum. Komposisi bahan dan kandungan nutrien pakan masing-masing disajikan dalam tabel 1 dan tabel 2.

Tabel 1. Komposisi bahan pakan penelitian

\begin{tabular}{lccc}
\hline \multirow{2}{*}{ Bahan (\%) } & \multicolumn{3}{c}{ Perlakuan } \\
\cline { 2 - 4 } & $\mathrm{A}$ & $\mathrm{B}$ & $\mathrm{C}$ \\
\hline Konsentrat & 20 & 20 & 20 \\
Jagung kuning & 40 & 40 & 40 \\
Dedak padi & 40 & 40 & 40 \\
Starbio & 0 & 0,20 & 0,40 \\
\hline
\end{tabular}

Tabel 2. Kandungan nutrisi pakan penelitian

\begin{tabular}{lrr}
\hline \multicolumn{1}{c}{ Komposisi nurien } & Kandungan nutrien & Kebutuhan $^{*}$ ) \\
\hline ME (kkal/kg) & 2549,60 & 3360 \\
Protein kasar (\%) & 15,76 & 18 \\
Serat kasar (\%) & 8,92 & $6-8$ \\
Lemak (\%) & 7,40 & $4-13$ \\
Ca (\%) & 1,24 & 0,65 \\
P (\%) & 1,00 & 0,50 \\
\hline
\end{tabular}

$\left.{ }^{*}\right)$ Parakkasi (1990)

\section{Rancangan Penelitian}

Rancangan penelitian yang digunakan dalam penelitian ini adalah rancangan acak kelompok (RAK) yang terdiri atas tiga perlakuan dan empat kelompok berat badan babi landrace. Ketiga perlakuan tersebut adalah pakan dengan $40 \%$ dedak padi tanpa suplementasi starbio sebagai kontrol (perlakuan A); pakan dengan 40\% dedak padi dan suplementasi $0,20 \%$ 
starbio (perlakuan B); dan pakan dengan 40\% dedak padi dan suplementasi $0,40 \%$ starbio (perlakuan C).

Kelompok 1 dengan berat badan $34,50 \pm 1,08 \mathrm{~kg}$; kelompok 2 dengan berat badan 26,83 $\pm 2,25 \mathrm{~kg}$; kelompok 3 dengan berat badan 24,17 $\pm 0,40 \mathrm{~kg}$; dan kelompok 4 dengan berat badan 21,83 $\pm 1,31 \mathrm{~kg}$. Masingmasing kelompok terdiri atas 3 ekor, sehingga dalam penelitian ini diperlukan 12 ekor babi landrace dan setiap kandang ditempati oleh 1 ekor babi landrace.

\section{Variabel yang Diamati}

Variabel yang diamati dalam penelitian ini terdiri atas: penampilan babi landrace (konsumsi pakan, pertambahan berat badan (PBB), FCR, DE dan PER) serta profil kotoran (kadar amonia, total E. coli, coliform, dan total mikroba).

\section{Analisis Statistika}

Data yang diperoleh dianalisis dengan analisis sidik ragam dan bila diantara perlakuan terdapat perbedaan yang nyata $(\mathrm{P}<0,05)$, maka analisis dilanjutkan dengan uji jarak berganda dari Duncan (Steel dan Torrie (1989).

\section{HASIL DAN PEMBAHASAN}

Rataan konsumsi pakan selama enam minggu pada babi landrace yang diberi pakan perlakuan dedak padi 40\% tanpa suplementasi starbio (perlakuan A) 88,855 $\mathrm{kg}$ /ekor (Tabel 3). Konsumsi pakan babi landrace yang diberi perlakuan pakan dedak padi 40\% dengan suplementasi starbio 0,20\% (perlakuan B) 13,36\% lebih rendah dibandingkan dengan perlakuan $\mathrm{A}(\mathrm{P}<0,05)$. Konsumsi pakan babi landrace yang diberi perlakuan pakan dedak padi $40 \%$ dengan suplementasi starbio 0,40\% (perlakuan C) sebanyak 4,15\% lebih rendah dibandingkan dengan perlakuan $\mathrm{A}(\mathrm{P}<0,05)$, sedangkan perlakuan $\mathrm{C}$ 10,78\% lebih tinggi dibandingkan dengan perlakuan $\mathrm{B}(\mathrm{P}<0,05)$.

Tabel 3. Pengaruh suplementasi starbio dalam pakan dengan $40 \%$ dedak padi terhadap penampilan babi landrace.

\begin{tabular}{lrrrr}
\hline \multirow{2}{*}{ Variabel } & \multicolumn{3}{c}{ Perlakuan $^{1)}$} & \\
\cline { 2 - 4 } & \multicolumn{1}{c}{$\mathrm{A}$} & \multicolumn{1}{c}{$\mathrm{B}$} & \multicolumn{1}{c}{ C } & \multicolumn{1}{c}{ SEM $^{2)}$} \\
\hline Konsumsi pakan (kg/ekor) & $88,855^{\mathrm{a} 3)}$ & $76,980^{\mathrm{b}}$ & $85,283^{\mathrm{a}}$ & 1,102 \\
DE (Mkal/ekor) & $283,712^{\mathrm{b}}$ & $336,880^{\mathrm{a}}$ & $321,253^{\mathrm{a}}$ & 7,14 \\
PBB (kg/ekor) & $28,250^{\mathrm{b}}$ & $33,875^{\mathrm{a}}$ & $31,750 \mathrm{a}$ & 0,676 \\
FCR & $3,12^{\mathrm{a}}$ & $2,28^{\mathrm{c}}$ & $2,69^{\mathrm{b}}$ & 0,063 \\
PER & $1,917^{\mathrm{a}}$ & $2,60^{\mathrm{b}}$ & $2,58^{\mathrm{b}}$ & 0,116 \\
\hline
\end{tabular}

Keterangan:

1) Pakan dengan $40 \%$ dedak padi tanpa suplementasi starbio (perlakuan A); dengan suplementasi $0,20 \%$ starbio (perlakuan B); dan dengan suplementasi $0,40 \%$ starbio (perlakuan C).

2) $\mathrm{SEM}=$ Standard Error of the Treatment Means

3) Superskrip huruf yang sama pada baris yang sama berbeda tidak nyata $(P>0,05)$

Konsumsi pakan yang paling tinggi terjadi pada babi landrace dengan pakan $40 \%$ dedak padi tanpa suple- mentasi starbio (perlakuan A). Hal ini terlihat jelas bahwa suplementasi starbio mengakibatkan meningkatnya DE pakan. Pada pakan dengan tingkat energi (DE) yang lebih rendah (A) pada Tabel 3, ternak akan mengkonsumsi pakan lebih tinggi untuk pemenuhan kebutuhan energi (Supnet, 1980 dalam Putri, 1994). Penggunaan dedak padi yang tingi dalam pakan menyebabkan meningkatnya kadar serat kasar dalam pakan sehingga laju aliran pakan dalam saluran pencernaan meningkat dan sebagian fraksi energi neto akan hilang untuk gerak peristaltik usus, sehingga babi akan mengkonsumsi pakan lebih banyak (Lloyd et al., 1978).

Suplementasi starbio dalam pakan babi telah nyata dapat menurunkan konsumsi pakan, meningkatkan DE, meningkatkan pertambahan berat badan, meningkatkan PER dan menurunkan FCR (Tabel 3, perlakuan B dan C). Hal ini disebabkan starbio dalam pakan telah meningkatkan aktivitas enzimatiknya untuk membantu meningkatkan aktivitas pencernaan, sehingga ketersediaan nutrien bagi babi landrace akan meningkat, sehingga pertambahan berat badan babi landrace juga meningkat. Perlu dikemukakan di sini bahwa, menurut Sartika et al. (1994), starbio terdiri atas multimikroorganisme yang menghasilkan enzim yang mampu memecah lignin, selulosa, lignoselulosa, protein dan lemak. Pencernaan enzimatik terhdap sumber-sumber karbohidrat dan protein menyebabkan ketersediaan sumber energi dan asam-aam amino bagi babi untuk melakukan aktivitas pertumbuhan.

Pertambahan berat badan babi landrace selama enam minggu pada pelakuan A memiliki rataan 28,250 $\mathrm{kg} /$ ekor (Tabel 3). Rataan pertambahan berat badan babi perlakuan B dan C masing-masing $19,91 \%$ dan $12,39 \%$ lebih tinggi dibandingkan dengan perlakuan A $(\mathrm{P}<0,05)$, sedangkan pada perlakuan $\mathrm{C} 6,27 \%$ lebih rendah dibandingkan perlakuan $\mathrm{B}(\mathrm{P}>0,05)$.

Rataan nilai FCR pada babi landrace perlakuan A sebesar 3,12 (Tabel 3). Nilai FCR pada perlakuan B dan C masing-masing 26,92\% dan $13,78 \%$ lebih rendah dibandingkan perlakuan $\mathrm{A}(\mathrm{P}<0,05)$, sedangkan rataan nilai FCR pada perlakuan $\mathrm{C} 13,78 \%$ lebih rendah dari perlakuan A $(\mathrm{P}<0,05)$, akan tetapi $17,98 \%$ lebih tinggi dibandingkan dengan perlakuan $\mathrm{B}(\mathrm{P}<0,05)$. Rataan nilai DE pada perlakuan A sebesar 283,712 Mkal (Tabel 3). Rataan nilai DE pada perlakuan B dan C masingmasing $18,74 \%$ dan 13,23\% dibandingkan dengan perlakuan A $(\mathrm{P}<0,05)$, sedangkan pada perlakuan $\mathrm{C}$ 4,64\% lebih rendah dari perlakuan $\mathrm{B}(\mathrm{P}>0,05)$.

Rataan nilai PER pada perlakuan A adalah 1,917 (Tabel 3). Nilai PER pada perlakuan B dan C masingmasing 2,60 dan 2,58. Secara statistika berbeda nyata $(\mathrm{P}<0,05)$ dibandingkan dengan $\mathrm{A}$, sedangkan antara perlakuan $\mathrm{B}$ dan $\mathrm{C}$ menunjukkan berbeda tidak nyata $(\mathrm{P}>0,05)$. 
Menurunnya konsumsi pakan dan meningkatnya pertambahan beratbadan padababi-babiyang mendapat pakan dengan dedak padi $40 \%$ yang disuplementasi dengan $0,20 \%$ (B) dan $0,40 \%$ starbio (C), karena meningkatnya ketersediaan energi dan protein serta sumber-sumber nutrien lainnya sebagai akibat dari peningkatan pross-proses enzimatik di dalam saluran pencernaan babi tersebut. Kejadian ini dapat dikatakan pula bahwa penambahan starbio ke dalam pakan babi akan meningkatkan efisiensi penggunaan pakan. Terlihat jelas pada perlakuan B dan C, dimana terjadi peningkatan angka PER dan penurunan angka FCR.

Rataan kadar amonia kotoran babi landrace yang diberi perlakuan A $61,673 \mathrm{mg} / \mathrm{kg}$ (tabel 4). Perlakuan B memiliki kadar amonia 13,27\% lebih rendah dari perlakuan $\mathrm{A}(\mathrm{P}<0,05)$, sedangkan perlakuan $\mathrm{C}$ memiliki rataan kadar amonia 2,94\% lebih rendah dari perlakuan A $(\mathrm{P}<0,05)$ dan $34,58 \%$ lebih tinggi dari perlakuan $\mathrm{C}$ $(\mathrm{P}<0,05)$.

Tabel 3. Pengaruh suplementasi starbio dalam pakan dengan $40 \%$ dedak padi terhadap profil kotoran babi landrace.

\begin{tabular}{|c|c|c|c|c|}
\hline \multirow{2}{*}{ Variabel } & \multicolumn{3}{|c|}{ Perlakuan ${ }^{1)}$} & \multirow{2}{*}{$E M^{2)}$} \\
\hline & $A$ & $B$ & C & \\
\hline dar amonia & $61,673^{a 3}$ & $53,489^{c}$ & $58,859^{b}$ & 0,536 \\
\hline . coli (koloni/ml) & $2,745 \times 10^{7 a}$ & $2,277 \times 10^{7 b}$ & $1,642 \times 10^{7 c}$ & 0,027 \\
\hline oliform (koloni/ml) & $7,655 \times 10^{7 a}$ & $4,945 \times 10^{7 b}$ & $2,625 \times 10^{7 c}$ & 0,162 \\
\hline ml. mikroba (populasi/ml) & $14,930 \times 10^{4 a}$ & $2,422 \times 10^{4 b}$ & $1,557 \times 10^{4 b}$ & 0,071 \\
\hline \multicolumn{5}{|c|}{$\begin{array}{l}\text { Keterangan: } \\
\text { 1) Pakan dengan } 40 \% \text { dedak padi tanpa suplementasi starbio (perlakuan A); dengan } \\
\text { suplementasi } 0,20 \% \text { starbio (perlakuan B); dan dengan suplementasi } 0,40 \% \text { starbio } \\
\text { (perlakuan C). } \\
\text { 2) SEM = Standard Error of the Treatment Means }\end{array}$} \\
\hline Superskrip huruf yang sar & & 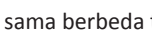 & ak nyat & \\
\hline
\end{tabular}

Rataan jumlah E. coli kotoran babi landrace yang diberi perlakuan A adalah 7,655 x 107 koloni/ml (Tabel 4). Pada perlakuan B dan $C$ memiliki jumlah rataan $E$. coli masing-masing 17,05\% dan 40,18\% lebih rendah dibandingkan dengan perlakuan $\mathrm{A}(\mathrm{P}<0,05)$, sedangkan pada perlakuan A $27,89 \%$ lebih tinggi $(\mathrm{P}<0,05)$ dibandingkan perlakuan $\mathrm{B}$.

Rataan jumlah coliform kotoran babi lanrace yang diberi perlakuan A adalah 2,475 x $10^{7}$ koloni/ $\mathrm{ml}$ (Tabel 4). Rataan jumlah coliform pada perlakuan B dan C masing-masing 35,40\% dan 65,71\% lebih rendah dibandingkan perlakun $\mathrm{A}(\mathrm{P}<0,05)$, sedangkan pada perlakuan $\mathrm{C}$ 35,71 lebih tingghi dari perlakuan B $(\mathrm{P}<0,05)$.

Rataan jumlah mikroba pada kotoran babi landrace yang diberi perlakuan A adalah $14,930 \times 10^{4}$ populasi $/ \mathrm{ml}$ (Tabel 4). Rataan populasi mikroba pada perlakuan B dan $\mathrm{C}$ masing-masing 83,78\% dan 89,57\% lebih rendah dibandingkan perlakuan $\mathrm{A}(\mathrm{P}<0,05)$, sedangkan pada perlakuan $\mathrm{C} 35,71 \%$ lebih tinggi dibandingkan dengan perlakuan $\mathrm{B}(\mathrm{P}<0,05)$.
Hasil penelitian menunjukkan pada kotoran babi yang mendapat pakan yang disuplementasi starbio (perlakuan B dan C) memiliki kadar amonia lebih rendah dibandingkan dengan yang tidak mendapat suplementasi starbio (perlakuan A) (Tabel 4). Hal ini disebabkan starbio yang disuplementasi dalam pakan dapat meningkatkan kecernaan protein pakan, sehingga protein yang terbuang melelui feses menurun. Gas amonia ini berasal dari perombakan protein yang terkandung dalam feses. Protein dalam feses dipecah oleh mikroba menjadi asam amino dan mengalami proses deaminasi dan desimilasi menghasilkan amonia (Sihombing, 1997).

Penggunaan starbio dalam pakan dapat menekan jumlah E. coli, coliform dan mikroba dalam feses babi. Hal ini disebabkan keberadaan starbio dalam saluran pencernaan mampu memproduksi hidrogen peroksida $\left(\mathrm{H}_{2} \mathrm{O}_{2}\right)$ yang dapat menghambat pertumbuhan organisme tersebut (Ritonga. 1992). Keberadaan starbio disamping menekan pertumbuhan $E$. coli, juga dapat meningkatkan kadar vitamin $\mathrm{B}_{12}$, $\mathrm{E}$ dan $\mathrm{K}$ dalam saluran pencernaan serta menurunkan $\mathrm{pH}$ dalam saluran pencernaan sehingga $E$. coli dan coliform tidak dapat tumbuh (Sand dan Hankin (1976).

Dari hasil penelitian ini dapat disimpulkan sebagai berikut: (1). Suplementasi starbio dalam pakan $40 \%$ dedak padi mampu meningkatkan digestible energy (DE), pertambahan berat badan (PBB), dan protein effisiency ratio (PER) serta menurunkan konsumsi ransum dan angka feed covertion ratio (FCR). (2). Suplementasi starbio dalam pakan juga mampu memperbaiki profil kotoran babi landrace dengan menurunkan kadar amonia, jumlah koloni E. coli, coliform dan jumlah mikroba.

\section{SARAN}

Penggunaan starbio dalam pakan yang berbasis dedak padi dapat dilakukan dengan penambahan $0,2 \%$ starbio. Karena dari hasil penelitian di atas terlihat bahwa penggunaan dedak padi sebanyak 40\% dengan suplementasi $0,2 \%$ starbio menghasilkan performans babi landrace paling baik.

\section{DAFTAR PUSTAKA}

Lloyd, L.E., McDonald B.E., and Crampton E.W. 1978. The carbohyrates and the metabolism In: Fundamental of Nutrition. 2 nd Ed. W.H. Freeman and Co, San Francisco.

Parakkasi, A. 1990. Ilmu Nutrisi dan Makanan Ternak Monogastrik. Cetakan ke-10. Penerbit Angkasa, Bandung.

Putri, T.I. 1994. Perbaikan lemak tubuh dan karkas babi dengan ransum yang mengandung bungkil inti kelapa sawit. Tesis. PPs. Univ. Gajah Mada, Yogyakarta. 
Rasyaf, M. 1994. Bahan Makanan Unggas di Indoonesia. Penerbit Kanisius, Yogyakarta.

Ritonga, H. 1992. Bakteri sebagai pemicu pertumbuhan. Poultry Indonesia, No. 14/April 1992. Hal 11-13.

Sand, D.C. and Hankin, L. 1976. Fortification of food by fermentation with lysine excreting mutans of Lactobacilli. J. Agric. Food. Chem. 24.

Sartika, T,Y., Raharjo C., dan Dwiyanto K. 1994. Penggunaan probiotik starbio dalam ransum dengan tingkat protein yang berbeda terhadap performans kelinci lepas sapih. Balitnak Ciawi, Bogor. Sains Majalah Ilmiah UNIV. Diponegoro, Semarang.

Scott, M.L., Nesheim C., and Young R.J. 1992. Nutrition of The Chicken. Publ. By M.L. Scott an Associates Ithaca, New York.
Sihombing, D..T.H. 1997. Pendaurulangan dan Penanganan Kotoran Ternak. Fak. Peternakan IPB, Bogor.

Steel, R.G.D. and Torrie J.H. 1989. Principles and Procedures of Statistics. 2nd Ed.. McGraw-Hill Int. Book Co., London.

Vestegen, M., Tamminga S., and Greers R. 1999. Pengaruh Pencemaran |Gas Terhadap Hewan: dalam Pencernaan pada Sistem Produksi Ternak. Penyunting: Dewi A. et al.. CV IKIP Semarang Press, Semarang.

Zainudin, D.K., Dwiyanto dan Suharto. 1995. Utilization of probiotic Starbio in broiler diet with different levels of crude fibre. Bull. Anim. Sci. T.W. Murti, K.A. Santoso, Suhartanto, Zubrizal, A.Wibowo (Ed). Publ. Of Anim. Gajah Mada University Press. 